\title{
Lip and Oral Cavity Cancer cM1 TNM Finding v8
}

National Cancer Institute

\section{Source}

National Cancer Institute. Lip and Oral Cavity Cancer CM1 TNM Finding v8. NCI

Thesaurus. Code C132724.

Lip and oral cavity cancer with distant metastasis. (from AJCC 8th Ed.) 